\title{
Montpellier Vitalism and the Emergence of Alienism in France (1750-1800): The Case of the Passions
}

\section{Philippe Huneman}

Institute for the History and Philosophy of Science and Technology, Université Paris I-Sorbonne

\section{Argument}

This paper considers how certain ideas elaborated by the Montpellier vitalists influenced the rise of French alienism, and how those ideas framed the changing view of passions during the eighteenth century. Various kinds of evidence attest that the passions progressively became the focus of medical attention, rather than a theme specific to moralists and philosophers. Vitalism conceived of organisms as animal economies understandable through the transformations of the various modes of their sensibility. This allowed some physicians to define a kind of anthropological program, which viewed human beings as a whole, with no distinction between le physique and le moral. The passions in this context became a specific alteration of the animal economy. Such an anthropological program was the framework within which Pinel understood the various classes of madness as disease - those troubles being general disturbances of the animal economy, which presupposed a knowledge of the latter, to be addressed and cured. In this view, and departing from the vitalist writers with regard to the specificity of mental illness as such, Pinel proposed another conception of the relations between passions and madness, and elaborated a general view of their status in etiology and therapeutics; those views were taken up and systematized by Esquirol, who finally defined a new kind of continuity between passion and madness, demonstrated by the idea that some kinds of madness that he called "monomania" had as a principle a "ruling passion" that the alienist, this novel medical specialist, had to unveil and address.

In the seventeenth century, authors frequently wrote treatises on the passions. "Passion" then referred to the articulation between a moral discourse and an "anthropological" project (using the latter term in its present sense). If we skip forward 150 years, we find Esquirol writing his dissertation in psychiatry, Des Passions considérées comme causes, symptômes, et moyens curatifs de l'aliénation mentale (1805). He is the first follower of Philippe Pinel credited with having formulated in a theoretical discourse the visions and projects of his master's Traité médico-philosophique sur l'aliénation mentale ou la manie (1802), as well as Pinel's alienist practice, which contributed significantly to the emergence of psychiatry in the late eighteenth century (Swain 1978). ${ }^{1}$ Clearly,

\footnotetext{
${ }^{1}$ This paper focuses on the emergence of psychiatry in France with Pinel and Esquirol, and thus does not make claims regarding the birth of psychiatry as a whole. English practices of therapy and madhouses and German medical anthropologists like Plattner or Unzer were at least as influential in this process of emergence of a kind
} 
passions are no longer the center of an anthropology or an ethics, but rather of a discourse about man's mental illness, and of a practice intended to be its therapeutic assessment.

How was this shift possible? I will consider only one aspect of this broad question: the nature of the eighteenth-century anthropological discourse upon which the alienists relied as a program that was distinct from the earlier treatises on passions and the basis for a new construction of the passions as a theoretical object. In this new discourse, the passions play a role in thematizing insanity that is very different from the role involved in the classical dialectics of reason and passion (see, e.g., Bénichou 1988 and Goldmann 1955 on passions in the early modern era), or even different from the role passions played in the anthropological image of man as a stable equilibrium between conflicting passions that we had found in the early modern era. ${ }^{2}$ Therefore one may wonder how - and from which breaks and discontinuities - did a peculiar relationship between passions and madness emerge in the eighteenth century, a relationship that enabled the formation of this early nineteenth-century knowledge within which the theoretical consistency of the passions is only possible according to the discourse proper to an incipient medical specialty, on the border between the medical and the judiciary namely, psychiatry?

I will argue here that, at least in early modern France, the context of such an anthropological shift is provided by the scheme of the "animal economy" developed by vitalist medicine in the second half of the eighteenth century. Granted, physiologists in the eighteenth century very often made use of the phrase "animal economy." Yet this came to denote a very precise scheme in the vitalistic context, widely disseminated by the vitalist physicians of the Encyclopédie - among them, Ménuret de Chambaud and Fouquet. The first French "alienists," Pinel and Esquirol, were quite aware of this scheme, which formed the framework of their claim that madness was a specific disease, and which, as I will argue, will to some extent frame their own approach that regarded passions as a theoretical object proper to psychiatrists.

of knowledge as well as a discipline. For the emergence of psychiatry in Germany, see Kauffmann 1995; in England, see Porter 1987, Scull 1979, 1990, and 1993; for America, and for a comparison, see Porter 2003. However, the present paper focuses on a specific issue that has been involved in this process, and involved in a particular manner in the French context, namely, the case of the passions. The present arguments do not propose a new interpretation of "the" birth of psychiatry: they do not bear on the issues of professionalizing psychiatry, which became important later (Goldstein 1987). The present arguments concern a very small subset of the processes that led to a new discipline, and mostly in France, in their relation with the earlier vitalistic tradition in medicine. Hence I mainly contrast the motif of the passions here with earlier French "treatises on the passions" from the classical, post-Cartesian era.

${ }^{2}$ Foucault's concept of déraison (Foucault 1965) is intended to capture the relations of reason and madness as they were framed in the classical episteme. Somehow, the various figures of the relationship between passion and reason here mentioned are included in the very idea of déraison. Yet the following analyses will depart in important ways from the thesis that a specific and structured view of déraison informed ideas and practices of madness from the Renaissance era to the post-Pinelian period. 


\section{Sensibility and the "animal economy"}

We cannot find a precise meaning of the term "animal economy," since in most medical schools, Boerhaavian, Hallerian, or Scottish, it is used with reference to the organism. But in some of these traditions, it encompasses a genuine research program in the life sciences - for example in French vitalism, after the mid-eighteenth century, it encompassed the main vitalist thesis, first formulated by Lacaze (Idée de l'homme an physique et au moral, 1755) and Bordeu (Recherches sur les glandes, 1751), according to which life is essentially the "sensibility" of the fibers which constitutes the organism. ${ }^{3}$ De Sèze, another Montpellier vitalist, claims: "Feeling is attached to all the animal fibers" (Le sentiment est attaché à toutes les fibres animale) (De Sèze 1786, 34). For Bordeu, each organ possesses its own sensibility, hence its "particular life," the life of the organism being the sum of all these lives - which is called an "animal economy," the term "economy" here really denoting a collection of individuals. All those authors were of course discussing Haller's important thesis that organisms have two irreducible properties, "irritability" and "sensibility," the latter being proper to animals because it is tied to the nervous system. Part of the self-definition of French vitalism was elaborated through a discussion of Haller's thesis, and a restriction to sensibility newly defined (with no reference to a nervous system, i.e., a central organ). ${ }^{4}$ This allows us to make an important distinction between soul and vital principle, properties, or forces: for Haller, sensibility attached stimulations to a soul, connected to the nervous system - whereas irritability was proper to the organism as such. The Montpellier vitalists replaced this pair of properties with sensibility alone, thereby depriving it of its relationship to a soul. Barthez, introducing the "vital principle" to account for manifestations of life, similarly avoided the reference to a soul in order to understand vital phenomena.

On the other hand, specifying our notion through a quick comparison, in the contemporary English physiology, the term "animal economy" referred to the central role played by the nervous system in understanding organisms. William Cullen for instance, tried to substitute his "nervous power" for Hallerian irritability: for him, sensibility and irritability exclude each other, since receiving an impression implies a weakness of the nervous power, whereas propagating the impression requires strength of this "nervous power" (Cullen 1761, 12). I am focusing here on the French brand of vitalism in Montpellier authors such as Bordeu and Barthez, following Boissier de Sauvages, who taught at Montpellier during the first decades of the century. It is very different from the English or Scottish variant, with Cullen (following a Cambridge Platonist tradition), or from the German one (with Gaub and Unzer among others)

\footnotetext{
${ }^{3}$ The presentation of animal economy here is short since the paper by Wolfe and Terada (in this issue) presents a complete and insightful view of such a research program in the vitalist context. I have also more extensively discussed the animal economy in Huneman 2007 and 2008. Williams 2003 provides an extensive survey of the emergence of Montpellier vitalism. On the fibers in this medicine, see Grmek 1970.

${ }^{4}$ On Haller and this criticism, see Steinke 2001 and 2005.
} 
which will lead to a generalized use of vital forces, relying on Haller's notion of irritability but transforming it through a reference to other forces like electricity, Galvanism, etc., ${ }^{5}$ and making use of philosophical conceptions like the criticisms of mechanism by Leibniz or Stahl at the beginning of the century.

Ménuret's definition of "animal economy" in the Encyclopédie can help us to grasp the research program encapsulated in such a scheme.

This term, taken in the most exact and common sense, refers only to the order, mechanism, and overall set of the functions and movements which sustain life in animals, the perfect, universal and constant exercise of which, performed with ease and alacrity, is the flourishing state of health, the least disturbance of which is itself illness, and the full ceasing of which is the extreme, diametrical opposite of life, that is, death. (Enc. XV, 362a)

An economy means an order of instances, and an exchange between parts. These exchanges are ensured by the sensibility inherent to each part. Extending Bordeu's idea of the sentient glands to the whole organisms we can track the "sympathies" linking two distant parts of the body, such as the vocal and genital organs during puberty, those sympathies being distinct from the nervous trajectories.

Besides looking for sympathies, subscribing to the scheme of animal economy means identifying the main centers of this economy and their hierarchies and linkages. We can pick out three main centers, ruled by the universal "law of action and reaction": the gastric center (that is, diaphragm and other organs placed around it); the head, the center of the nervous system; and the skin, which was termed the "organe exterieur," namely, the external milieu for the organism.

Nevertheless, the animal economy is involved in a general economy, through its relationship with a milieu. It exchanges elements, which may be either "moral" or "physique." Ménuret says of the head that it must be "considered as an organ which is immediately altered by the affections of the soul, the sensations, the passions, etc" (considérée comme organe immédiatement altéré par les affections de l'ame, les sensations, les passions, \&c.) (Enc. XI, 364a). So, the general principle of sensibility, entailing that organs as such, and by extension organisms within their milieu, can be sensitive to anything, makes mental events as well as physical affections likely to cause any change in animal economy. There is a continuity between sensation as understood by empiricist philosophers of the time (e.g. Condillac) and the sensibility of physiologists since Haller and the vitalists, a continuity which legitimizes a systematic consideration of body and soul in the same physiological discourse. One late witness of this systematic view is Bichat, in the Recherches physiologiques sur la vie et la mort: distinguishing "sensibilité organique" (pertaining to the organism related to itself) and "sensibilité animale" (concerning the relational life of the organism), he stresses the continuity between both, exemplified by the swallowing of a nutrient, that we initially

${ }^{5}$ See, for example, Reill 2005 on this German idea of vitalism. 
feel in the throat and trachea, then we progressively cease to feel it, transferring the affect to the "sensibilité organique." 6 This sort of indifferentism regarding body and mind, proper to such a medical view and likely to turn it into an anthropology - termed "histoire naturelle de l'homme"7 -, makes the passion a proper object of medical studies. ${ }^{8}$ For Bichat indeed, this articulation between the two sensibilities was a reason to ascribe passions originally to "organic life" rather than "animal life" ("vie de relation"), hence to make it primarily into an object of medicine. One should not conflate Bichat's forces with Bordeu's sensibility and Barthez's vital principle, because of course the former were embedded in a dual project of experimental physiology and pathological anatomy that the latter absolutely lack, being much more tied to observation and clinical medicine. Notwithstanding this caveat, the inclusion of those forces in the essence of life, their "plastic" nature and the irreducibility of their knowledge to a nomothetic explanation, all those elements place Bichat in a continuity with the Montpellier vitalists and allow us to consider his approach to the passions as somehow correlated to the positions on anthropology and passions that medical vitalism allowed five decades earlier. Even prior to Montpellier vitalism, inaugurating in some way this set of concepts and beliefs that was structured into the scheme of the "animal economy" discussed here, Buffon conceived of a displacement of "passions" from "soul" to organism akin to Bichat's move:

Compassion: the term conveys well enough [the idea of] suffering, a shared passion; yet it is less the man who suffers, than his nature which responds, which mechanically revolts and of its own accord identifies with the pain. The soul is less involved than the body in this feeling of natural pity, and animals are just as capable of it as man is; a cry of pain moves them, they come running to succor one another, they draw back at the sight of a corpse from their species. Hence horror and pity are less passions of the soul than natural affections, which depend on the sensibility of the body and the similarity of conformation; this sentiment should then diminish in proportion to increasing lack of similarity between natures. A dog being beaten, a lamb being slaughtered, cause us some pity; a tree being cut down, an oyster being bitten, cause us none. ${ }^{9}$

\footnotetext{
${ }^{6}$ Bichat 1800, and commentary in Huneman 1998.

${ }^{7}$ On the anthropological program, see Huneman 2007, and Blanckaert 2002. Cabanis took the phrase from Buffon.

${ }^{8}$ Note that, besides their discussion of Haller, an important influence on the vitalist physicians was Buffon's idea of organism, animal economy, and sympathies, for example in the "Discours sur la nature des animaux" (1749): "we find the greatest diversity in the outer layers, but all have, conversely, more or less the same internal structure [conformation]; they all have a heart, a liver, a stomach, intestines, reproductive organs: these parts must then be considered as essential in the animal economy, since they are the most constant ones, the least subject to variety." Buffon focuses on the animal economy as diversely instantiated across the animal kingdom, in a way that universal generalities may still be captured.

${ }^{9}$ Buffon 1758, vol. 7 (“Les animaux carnassiers"), 7. For the relationships between Buffon and Montpellier vitalism, see Rey 1992.
} 
However, we need to avoid a possible misunderstanding here. Of course, medicine had not always been dualistic until this century, so that Montpellier vitalism would have been the origin of a novel, non-dualistic, view of life. On the contrary, there had been a long-lasting "unitary" conception of man in medicine, yielded by the most influential tradition, the Hippocratic one. As Theodore Brown noted, Cartesian dualism had been a parenthesis in this tradition, and a strongly misinterpreted parenthesis (Brown 1985). For this reason, as Barthez strongly emphasized, vitalistic thinkers conceived themselves as restorers of Hippocrates, after centuries of Galenic and Cartesian errors. ${ }^{10}$ But this renewal was in fact very different from the source. The main operating concept was not the humors - as in the Hippocratic tradition ${ }^{11}$ - but the sentient fiber, or organs. When Barthez subscribes to the idea of a vital principle acting within the economy, and responsible for the various organic manifestations, this principle has the same status as Newton's gravity - it is an X, an unknown whose only reality is given by the forces manifesting it (the reference to Newton's gravity as irreducible and metaphysically blind is a locus communis in the animal economy literature ${ }^{12}$ ). It is inheriting the status of Hallerian irritability - as an unknown explanatory and irreducible property - rather than the status of "soul" in the former dualistic conceptions of life. What is actually operative in the vitalist "animal economy" is the connection accountable by sympathies through communities of sensibility, rather than the dissimilarities and balance of the elementary humors.

That is why old concepts, like "sympathies," gained a new meaning as they were used in the vitalist research program. "Milieu" was not considered through the problem of balancing the four humors, as in the celebrated treatise On air, water, places, but as a source of affections in harmony - or disharmony - with sensibility as a whole. In fact, vitalism was not a return to Hippocratism, because humoralist models - initiated by Hippocrates - had long ago been supplanted by iatromechanism (which ignored the four humors in its explanation of living entities) - and iatrochemism such as Pitcairn's (which dissolved these humors into the ordinary chemical fluids). The end of humoralism, and then the critique of its main alternatives - e.g. iatromechanism, iatrochemism - necessarily had to lead to a new physiological and physical scheme, even formulated in some older terms. One has yet to acknowledge that Hippocratism was a strategic reference for those physicians (see Williams 2003), because it meant the reappropriation of the ancient ethics and was therefore entangled with the contemporary reappraisal of the Roman reference in political discourses - namely, emphasizing the idea of a République, etc. Hence, the references to Hippocrates here also played the role of putting vitalism, as a revolution in medicine, on a par with

\footnotetext{
${ }^{10}$ For example, see Barthez 1801; De Sèze 1786, Préface; Pinel, “Méthode d'étudier la médecine," in Pinel [1798] 1813, xii ff., xcii.

${ }^{11}$ Blood, black and yellow bile, and phlegm were associated with the physical four elements and four qualities.

In medicine, they could be linked with the four seasons. On this point, see Nutton 1993.

${ }^{12}$ See Wolfe and Terada (in this issue) for the Newtonian reference pervasive in vitalist medicine.
} 
revolutionary trends in early modern France, which allowed its contenders to vindicate a role in the organization of public health plans and policy in general. ${ }^{13}$

"Non-natural things" were another Hippocratic concept rediscovered and transformed by the animal economy medicine. The reactivated doctrine of causality through "non-naturals" bears important consequences for the reappraisal of passions by physicians. Introduced by the Arabic treatise Medical questions and answers by Hunan Ibn Ishaq (809-873), the Galenic doctrine of the non-naturals owes its form to Johanititus' Latin translation of the treatise in the eleventh century: against the "naturals," which concern the humors inside the body, ${ }^{14}$ the "non-naturals" mean the elements outside of it - but of course, also found in nature, like drinking or sleeping or moving - able to impinge on it. ${ }^{15}$ Reciprocally, it is possible to restore a humoral equilibrium in a gentle way by acting on those non-naturals, e.g. by taking a usual walk, or by travelling. Once again, here is Ménuret, in "EEconomie animale":

Six main causes which are essential to life, known in the Schools as the six non-naturals, namely, air, food and drink, movement and rest, sleep and waking, excretions and lastly the passions of the soul, maintain, by their rightful proportion this mutual agreement [accord], this perfect uniformity of functions which constitutes health; when they lose this balance, they become the general causes of illness. (Ménuret 1765c, Enc. XI, 365b)

Between the Hippocratists and Ménuret, the meaning of the non-naturals changed: formerly operators of a healthy humoral equilibrium, they became partners in an economy of exchanging affects and motions. The status of the passions is then paradigmatic of the shifting status of the non-naturals, now integrated within a general economy whose proper currency is the sensations, or feelings, both interchangeable through the general circulation of affections within animal economy and between itself and its milieu. A passion is worthy of anthropological study, not because it affects the humors, as in Hippocratism, ${ }^{16}$ nor because being the disturbance of the soul by the body, ${ }^{17}$ it reveals the strength of an inborn reason proper to the individual, as

\footnotetext{
${ }^{13}$ Swain and Gauchet 1980 treated in some detail the embedding of the French alienism within a general plan of de-theologizing politics and promoting equality instead of exclusion - alienists in this regard stood together with l'abbé de l'Epée, vindicating a sign language for deaf people, etc. Our specific case study does not contradict their general analyses. For the ulterior strategy of making psychiatry into a discipline after the 1820s, see Goldstein 1987.

${ }^{14}$ More precisely, the seven naturals were: elements, temperaments, humors, parts of the body, faculties, functions, and spirits.

15 The causes of disease, as such, are termed "contra natura"; these are pathological, while the non-naturals are normal or physiological.

${ }^{16}$ Brown emphasizes that, in the context of a theory of passions, joined with a theory of imagination and an understanding of the mind's effects on illness, "medical theory long before Descartes had established very clear precedents for a theoretical appreciation of the interaction of something very much like mind (psyche) with something very much like body (soma)" (Brown 1985, 41).

${ }^{17}$ The most radical formulation of this idea which will rule all the Treatises of passions in the classical age is of course given by Descartes himself in the Passions of the Soul: "In addition, I consider that we do not observe
} 
in classical ethics, but because it illustrates the possibility of obtaining the notion of animal economy through non-naturals, a possibility which is essential for the new anthropological project that considers animal economy as a whole, "au physique et au moral." To this extent, the correlation of madness and passions will acquire a new significance; although such significance could seem close to the credo of ancient psychiatry - furor iris breva (anger is short-lived madness), meaning that there is only a difference of degree between passion and insanity - it was actually as far from it as the vitalists' medicine was far from Hippocratism, notwithstanding the superficial claims of descendance.

\section{Passions, illness, madness: the new configuration}

\section{a. Passions for physicians}

In this context, the late 1700s saw the appearance of many writings on the role of passions in the etiologies of diseases. In France, Clément-Joseph Tissot published in 1798 De l'influence des passions de l'âme dans les maladies. He defines passions as: "a motion impressed on the fiber, by virtue of which it rises or falls" (4); therefore "passions are agreeable or unpleasant emotions, the overall effects of which are to contract or relax the fibers, to dilate or compress the organs" (34). In this context it makes sense to seek remedies for the bad influence of passions on diseases, and ways to enhance their healthy effect, as in the case of joy. In spite of professing a dualistic metaphysics, and believing in "animal spirits," his project and his method clearly make use of the "animal economy" scheme à la vitalism. For this reason, when an etiology is unknown, he recommends "examining if there might not be some extraordinary disorder of the soul which fuels the disorder of the functions" $(\$ 113,168)$ - clearly here the same meaning of non-naturals as in Ménuret. A few years earlier, Antoine Le Camus (1753) established a symmetrical program: medicine should know both minds and bodies, so it should know the way of perfecting the mind by acting on the body. Though his title suggests that Le Camus is a late Cartesian (since the Cartesian thesis is that passions are effects of the "union of body and mind" on the mind), his concrete assertions and his modus operandi, as well as the whole idea of his project, locate him in the framework of the vitalists' style "animal economy" medicine. ${ }^{18}$

anything which more immediately agitates our soul, than the body joined to it, and consequently we ought to conceive that what in that is a passion, is commonly in this an action; so that there is no better way to arrive at the understanding of our passions, than to examine the difference between the soul and the body, that we may know to which of them each function in us ought to be attributed" (Descartes 1649, §II, in Descartes 1996, AT XI, 328).

${ }^{18}$ Voltaire mocked Le Camus in his Dictionnaire philosophique, writing: “Ah! monsieur Camus, vous n'avez pas fait avec esprit la Médecine de l'esprit (Ah! Sir Camus, you did not write with wit the Medecine of the mind with an untranslatable joke on wit and mind, both rendered by "esprit" in French)" - precisely in the entry 
Passions, being properly nested in the animal economy, could either provoke a disease, or help or delay its curation. Several medical dissertations focused on this topic, for example Raimond Laroque's dissertation, De l'influence des passions sur l'économie animale considérée dans les quatre âges de la vie (Montpellier, An IV), or G. Royer's dissertation De l'influence des passions considérées sous le rapport médical (Paris, 1803). ${ }^{19}$ In the English-speaking medical arena, William Falconer published at the same time The Influence of Passions on the Disorders of the Body (1788). Hence Tissot belongs to this wide medical literature about passions, which indicates that passion was being transferred from the moralists' hands to the physicians'. This move is reflected in the dictionaries: in the Dictionnaire de l'Académie française, first edition 1694, the entry "passion" gives: "Passion. s.f. Movement of the soul excited in the concupiscent, or the irascible part" (199); in 1762, while retaining this definition, it adds: "PASSION is also the name given by Doctors to some very painful maladies, such as the hysteric vapours they call hysteric Passion, the so-called miséréré colic, which they call iliac Passion, etc." (320). Even if early modern physicians such as Van Helmont or Sydenham would sporadically mention the role of passions in the etiology of diseases, the systematic consideration of passion in medicine occurring after the middle of the eighteenth century is indicated both by the number of publications in a short period of time and by the taking into account its medical meaning in the revision of the dictionary.

The pivotal role of a reference to the animal economy in this shift is indicated when Laroque writes that each period of life has its peculiar passions, which during puberty are a real "disturbance of the laws of the animal economy" (12). ${ }^{20}$ Later, after Bichat had replaced the passions in the organs of the "organic life" (i.e. epigastric center, liver, etc.), Royer could draw a model of the genesis and action of passions into the animal economy. Issued from a sensation, i.e. an action in the brain, an affection can produce, once transmitted to viscera of "organic life," the phenomenon peculiar to a determinate passion. Then, by sympathy, this passion acquires a feed-back effect in the brain, which activates in a specific manner the organs of the "animal life," i.e. the voluntary muscles. That is why, though passions belong to the organic life, their expression involves muscles of the animal life. So, by following the sympathies we can

\footnotetext{
"Passions - leur influence sur le corps, et celle du corps sur elle (Passions: their influence on the body, and its influence on them)." Contrast Voltaire's attitude with Diderot's regarding Bordeu and the vitalists, and we see how Le Camus still belongs by his phrasing to a post-Cartesian context, but his vitalist followers, though using close concepts, will stimulate a very different philosophical reception by moving from a seemingly dualist discourse to that of the "animal economy."

${ }^{19}$ This interesting dissertation was defended in the midst of the medical and ideological renewal of the late eighteenth century: Chaussier, Fourcroy, Pinel, Desgenettes, Cabanis, Thouret, Hallé, Pelletan... This is certainly a sign of the major significance of such a problematic for the scientific world.

${ }^{20}$ The question of age in the animal economy is a frequent one; in the same year, it was also addressed by Joseph Franchet's Montpellier dissertation entitled Maladies affectées aux divers ages.
} 
understand how passions can cause diseases. ${ }^{21}$ That leads us to focus on the definitions of mental illness in this tradition.

\section{b. Passions and mental disorders in mid-1700s French medicine}

If one wishes for an insight into the multilayered conception of madness held in the mid-eighteenth century, on which the vitalists were a major influence, one could turn to the Encyclopédie, in which entries such as folie, manie, mélancolie, fureur, démence, frénésie, délire... (written chiefly by vitalist physicians such as Fouquet or Ménuret, but also by D'Aumont) display several different, coexisting theoretical commitments regarding insanity. Some entries, written by D'Aumont, display a traditional view of madness full of skeptical or Christian evaluations of insanity as an excess likely to be viewed as, from another viewpoint, a testimony of the excesses of worldly life (see Huneman 2004). Sauvages, whose nosology is constantly quoted by the Encyclopédie, assumes that, even if "madness" is a disease, constituting the eighth class of diseases (and named vesania), this madness is understood as a depravation: "When the main symptom is a depravation of the imagination, judgment, will or desire, this is madness, which the Latins called vesaniae because these functions are not healthy" (Sauvages 1772, I, §351, 322). Such a depravation stems from a mistake, which in the end implies the subject's wrong use of his or her reason: "The mistake stems not only from a bodily flaw, but also from our own contempt for our faculties, and our lack of care in searching for the truth or cultivating our judgment" (ibid., VIII, §21, 14). This equates madness and vice, as some individuals are "sick from an ailment contracted by the soul" (ibid.). And Sauvages also uses the vocabulary of excess: among the classes of "vesania," he counted hallucinations, delirium, and a third class named "bizarreries morositates," characterized by a peculiar mistake: little things are appreciated too highly, or the reverse; bizarrerie is "too great [a] desire or aversion for something" - therefore the will is depraved, since the subject "prefers a small good to a great one" (ibid., VIII, 192).

According to Pigeaud, ancient medicine divided the lunacies, attributing those diseases to which some bodily cause could be ascribed to medical practice, and "diseases of the mind" to philosophy (Pigeaud 2002). The former include mania, melancholia, and phrenesis (delirium with fever): the old and etymological correlation between melancholia and bile attests to this partition. The latter comprise passions of the soul, addressed primarily with the vocabulary of excess. But we see here that such a vocabulary pervaded medical discourse. Sauvages' clearly medical nosology, with this class of morositates, is a main illustration of this fact in the mid-eighteenth century, and testifies that the ancient relationships of madness and passions are about to be transformed.

${ }^{21}$ On this point, see Grange 1961, 451. On medical practices at those times, see Bynum 1998. 
Some other articles in the Encyclopédie do place a stronger emphasis on organic matters, for example "Manie" and "Mélancholie" by Ménuret. They feature an interesting ambiguity about whether there is a physical seat of insanity. Sauvages whose appraisal of madness is as ambivalent and multilayered as the Encyclopédie's entries are - had already stated that madness is a problem of circulation, which neutralizes the issue of its seat. There are two kinds of states able to contribute to madness: too much sensibility or vivacity of ideas; inertia or slowness of ideas (Sauvages, VIII, 37). Ideas here are treated as liquids in a hydraulic machine, with different velocities; they can be equated with the fibers which support them. For this reason, according to Sauvages, causes of those states can be either moral or psychical (ibid., VIII, 19.5) - because circulation can be conceived according to those two perspectives.

Here is the reason why, in mania, moral causes and physical alterations are both at work: while (1) the sympathy between brain and other centers of the "economy" explains the production of psychical symptoms, conversely (2) the moral affections clearly are possible causes of diseased organs.

Proposition (1) is formulated in the article "Manie," where Ménuret writes:

All these facts [sc. the anatomical observations on corpses], as we can see, shed no light on this theory; as we cannot add anything certain or even probable to it, we shall not dwell on it any further, and merely comment that there is necessarily a flaw in the idiopathic or sympathetic brain. The essential symptoms of mania arise because objects do not present themselves to the sick as they really are. The formation of ideas and perception are connected to the particular and determined motions of the brain fibers. (Ménuret 1765a, Enc. X, 33)

"Idiopathic or sympathetic brain" means that, whether the source of mania comes from a perturbation of the brain, or from a sympathetic impinging of any other organ into the brain, we will get the same effect. The brain fibers will be altered and hence mania stems from a damaged "apperception," given that apperception is an impression on the brain fibers, mediated through nervous sympathies. We must emphasize that, in this "animal economy," madness is no longer a mistake (i.e., a problem of judgment, which, at the end and in a Cartesian tradition, involves the subject's will and responsibility) but is a troubled apperception (which is the direct effect of the physiological state of the fibers). This major shift is a condition of emerging psychiatry, because the move carrying madness from ethics to medicine logically presupposes this replacement of the judgment by the perception.

Proposition (2) is systematically invoked in the Encyclopédie. "Mélancolie" states it as follows:

The causes of melancholy are roughly the same as those of mania (see this term): sorrows, suffering, passions and above all unfulfilled love and venereal lust are most commonly followed by melancholic delirium; vivid and continual fears also rarely fail to produce it; 
overly strong impressions caused by some over-zealous preachers, the excessive fears they provoke of the punishments with which our religion threatens those who break its laws these cause astonishing revolutions in weak minds. (Ménuret 1765b, Enc. X, 311)

While preserving the distinction between delirium and phrenesis, which originated in ancient medicine with Caelius, and setting apart a delirium due to organic illness with fever (phrenesis) from a more psychical delirium (without fever), D'Aumont also invokes moral causes for this disease:

\begin{abstract}
Dissections teach us that frenzy (phrénésie) is not caused by the inflammation of the meninx, nor parafrenzy by that of the diaphragm, but by the variscosal obstruction of the channels from the brain and the meninx: it is sometimes accompanied by a classical inflammation, sometimes not. Thus all the causes conditioning the obstruction of those parts are those of frenzy. Thus, sorrow, strength and long-lasting application of the mind to a single topic, pain, vivid passions such as wrath, fury, love, excesses of uteral fury, are equally causes of frenzy. (D’Aumont 1765c, Enc. XII, 530)
\end{abstract}

This is easy to understand, if we recall that the animal economy defined the essence of a fiber as sensitive: anything, whether a moral impression or a physical shock, can affect it and therefore produce a troubled apperception, then delirium. Hence passions clearly play a role at both levels: they are a paradigmatic example of a cause, but acquire their causal relevance within the net of sympathies proper to the animal economy. Notice this important shift: passions are plausible causes of some phrenesia (frenzy) - whereas in the ancient divisions of lunacies phrenesia, as "medical" disorders, were precisely the opposite of "moral" disorders, passions of the mind, treated by philosophy.

\title{
c. Medical taxonomies and vitalism: the case of mental disorders
}

Through sensibility viewed as the essence of life, the identity of the two realms - the moral and the physical, fibers and representations - entails a simple view of causes and classification of lunacies. Though a coherent classification is not achieved in the Encyclopédie, due to the plurality of authors and approaches, the question itself is raised and clearly illustrates the presuppositions of the various scientists at the mid-century.

"Manie" and "mélancolie" are defined, classically, as a generalized delirium, opposed to a delirium focused on a single idea: "this term refers to a universal delirium without fever, at least an essential one; this delirium is frequently furious, audacious, and angry, and then it should properly be termed mania" (Ménuret 1765a, Enc. X, 31).

Consequently, maniacs are often furious, while melancholic people can frame valid reasoning. Since Areteus, medical classification of chronic mental diseases, long ago named "diseases of the head," was bipolar, extending between mania and 
melancholia. ${ }^{22}$ Sauvages held the same distinction (maniacs do not reason, melancholic people do reason quite well on one false $\mathrm{idea}^{23}$ ). According to the Encyclopédie, which refers to Sauvages, this partition of madness can be assimilated to a classification of the perturbations of sensible fibers, or cluster of these. Mania is linked to a too strong stricture of all fibers, while melancholia strikes only some fibers; and dementia, which is a total lack of ideas, supposes a total weakness of the fibers' tension (see D’Aumont 1765a, Enc. IV, 785-788). So, "animal economy" allows something like an isomorphism between bodily structure and the taxonomy of lunacies. In such a configuration, madness can be thought of as a wholly medical matter. Even if this isomorphism belongs mostly to the Encyclopédie's imaginaire, the link between the insane and moral fault - as existing in the French tradition, e.g., amongst the classical moralists of the previous century, and still present in Sauvages (lunatics suffer from "depravation," they are "sick from an ailment contracted by the soul," see above) - is about to be broken.

\section{d. Double etiologies and passions in the animal economy}

To be sure, recognition of a mental etiology of illness, e.g., sorrow, violent joy, etc., or a physical etiology of madness, e.g., blow to the head, etc., is an ancient theme, but the emphasis in Montpellier vitalism on sensibility in the animal economy, or the English orientation toward a nervous center of this economy, allowed a unified frame for those conceptions, and a way to formulate some questions about those etiologies.

In this frame, the etiological role of passion may be understood through what could be called a "double etiology." Here, the scope of our enquiry exceeds the French vitalists and their legacy because it seems that this was part of a common medical language (or style of etiology) that has been pervasive across Europe, and to some extent may have accounted for the numerous circulating ideas between traditions, especially between French and English physicians. ${ }^{24}$ Illness, and particularly mental illness, has two causes, a predisposing one, and an occasional one. Sauvages states that the "efficient causes," which "effectively produce the illness," differ from the "conditions without which it couldn't occur" (Sauvages 1772, I, §155, 187). Cullen asserts at the same time that in hypochondria, moral causes bring about the disease, but the "bodily temperament determine those causes to produce their effect sooner or later" (Cullen 1784, §1229). Regarding epilepsy, he juxtaposes the collapsing causes - hard bleeding

\footnotetext{
22 On the history of this pair, and Areteus' comment that melancholia could indicate the beginning of mania, see Jackson 1986, chap. 10.

${ }^{23}$ Sauvages 1772, VIII, 28. Melancholia and mania belong together to the order of "delirium," which differs both from "hallucinations" and "morositates": delirium involves some "vice of the brain" (301).

${ }^{24}$ For an interesting account of how etiology, diagnosis, and therapeutics were practiced at the time in England, together with the specific social constraints acting on English asylums, focusing on Bedlam's director John Monro, see Scull and Andrews 2001.
} 
(ibid., §1301), terror (ibid., §1302) - with the predisposing causes, such as "motility," which indicates the state of mind (ibid., \$1307), and consists in "a more or less high degree of sensibility or irritability" (ibid., §1311). This double etiology spread through the medical literature on the diseases of mind throughout the century. ${ }^{25}$ Crichton uses it systematically, under the names of "exciting" and "predisposing causes." Delirium has its predisposing causes in heredity - heredity of character, of temper, hence of internal viscera. Anyway, the distinction is not so simple, because "a predisposition may be formed . . . by a continued operation of a number of causes" (Crichton 1798, I, 187). Exciting causes can be either "powerful stimuli" - which could equally be mental ("excessive use of mental faculties," "violent passions") or physical ("excessive heat," "translation of various inflammation to the brain") - or "diseased nervous impressions conveyed from different parts of the system to the brain" (ibid., 189). The first ones cause mostly "pure insanity," while the second provokes "temporary delusions." 26

Such a double etiology seems to repeat the old use of "constitution" and "temperament" by the physicians, chiefly humoralists. ${ }^{27}$ But in the French vitalist scheme of animal economy, we have a homogeneity of the causes, because to be a cause means to impinge on sensibility. To this extent, passions are putative causes because they move sensibility in exactly the same way as "heat" can do. And their timescale ranges them with the "exciting" causes for Crichton, but nothing precludes them to be "predisposing" causes if they can act in a long-lasting way - the "mental" dimension of passion does not restrict them to the class of stimulating causes. When, contemporaneously to Crichton, ${ }^{28}$ Pinel acknowledged that to understand a lunacy the doctor must know "the history of the passions" of a man, ${ }^{29}$ he clearly indicates that the effects of passions on the animal economy constitutes a strong predisposing cause, the knowledge of which is required if one wants to grasp the etiology of a kind of lunacy.

A double etiology can be legitimated when placed in a multiple-entry system of exchanges - an economy - inside of which a kind of single currency - sensibility (possibly identified with nervous power, in the English variant of animal economy) circulates and transforms itself. Exciting and predisposing causes become homogeneous, they can articulate one to another as modes of acting upon sensibility. (Their difference refers essentially to a different temporal structure, predisposition being more remote

\footnotetext{
${ }^{25}$ At the same time, Whytt 1765 identified two kinds of causes, "predisposing causes" (chap. 3), divided into weakness of a particular organ, and excessive delicacy of the whole nervous system ( $\$ 31)$, and occasional causes (chap. 4) which can be either local, or general, i.e. in blood ( $(53)$.

${ }^{26}$ We find a detailed version of the double etiology in Arnold 1782. He divided causes into "remote causes" and "proximate causes," and the remote causes could be either "bodily causes" (II, 10-11) or "mental causes," like, traditionally, "intense application of mind" or "passions of various kinds."

${ }^{27}$ For example, a predisposing cause of hypochondria, according to Cullen, is "rigidity of the solids," "lethargy of the nervous power," hence what he defined as "melancholic temper" (Cullen 1784, §1230).

${ }^{28}$ On Pinel and Crichton, see Swain and Gauchet 1980, 347-349.

${ }^{29}$ See the next section for a further analysis of this sentence and its Pinelian context.
} 
and acting at length, while exciting causes are quite present and more instantaneous.) In this case, ignoring one kind of cause even legitimizes seeking the other kind, as in the case of madness according to Cullen.

This double etiology is of course inherent to animal economy as such, so its validity includes mental and organic illness. Predisposing causes are either mental or physical, or related to the conditions of life. Due to the vitalistic emphasis placed on the "milieu," physicians have to investigate the situation of the patient in his environment in order to grasp those causes. Pinel states the point in his Médecine clinique, while he presents the medical method of settling a case. After having described the current state of disease, and regressed back to its origin, the physician must "search for the exciting and predisposing causes"; we will find them:

1. In the profession and way of life of the patient; 2 . In the accidents prior to the present illness, in the prior state of health; 3. Occasionally, in the illnesses that befell the parents of the patient. (Pinel [1798] 1813, 5)

Regarding mental illness, the double etiology then allows a potential combination of four elements, given the either mental or physical character of the predisposing and the exciting events. The classification of "névroses" in the Nosographie philosophique uses such double etiology: the subject is always divided into three rubrics, "predispositions and occasional causes," "symptoms," and "treatment."

In this situation, the desperate search for an organic lesion for an illness, paradigmatically a brain lesion, is of no scientific interest, since we already have the possibility to construe a valid etiology with animal economy concepts (sympathies, milieu, etc.). Hence the epistemological structure of double etiology makes perfect sense within the animal economy medicine, and enables those physicians interested in lunacy to view it - notwithstanding the variety of events included in its etiology and the variety of their natures, e.g. passions, hits, heat, way of life, etc. - as a specific disorder of animal economy. This disorder of course requires specific kinds of therapy.

\section{Healing the insane, handling the passions: animal economy and the reassessment of lunatics management}

\section{a. The views from the vitalists and their contemporaries}

Concerning the therapy of madness, for the vitalist tenants of animal economy, nothing is really new and the authors' examples often return to the ancients. Boerhaave treating anguished maniacs by terrorizing them still more is a classic example (Beauchesne 1781, 
149). ${ }^{30}$ But this disparity of practices is somehow justified and unified if we apply the scheme of "animal economy" as developed before.

Basically, treatments of the insane are disposed on two axes, which are shared by various medical schools across Europe: distract the insane patient from his diseased idea or fatal passion; change his way of life by a sudden shock. Medical practice realizes one of those two ideals, moral or physical. "Substitute new ideas," "violently stress the body," in the texts from the Encyclopédie quoted here, are paradigmatic illustrations of the two-sided healing practice in the period. Foucault will focus on this use of water in order to restore a state of health (Foucault 1965, 331-338). As he said, "from the end of the seventeenth century, curing through baths takes its place, or regains its place, among the major therapies of madness" (ibid., 334). However, the interest in sudden immersion of lunatics was medically justified by the therapeutic impact of violent stress as derived from the principles of the vitalist animal economy. This relying on a conceptual doctrine introduces a discontinuity in the history of treatments that Foucault overlooks, because he focuses on the cultural representations of madness with scant attention to the more fine-grained medical theories that have been mobilized to underpin those representations.

The same non-naturals that were etiologically relevant, like passions, thereby become therapeutic tools. The traditional use of fear and surprise by physicians are legitimized in this scheme: fear lessens excitement, consequently it should be opposed to it. ${ }^{31}$ Cheating the patient is another good expedient in curing melancholia (like hypochondria): physician shall use "artifices able to correct this imagination or this judgment" (ibid., §1592). The use of opposing affections also justifies terror. As Cheyne will say in his last book, Natural method of curing the diseases of the body, and the disorders of the mind depending of the body (1742), the physician must "break the false and nonnatural associations of ideas, or bring about counter-associations, and use one passion against another" (Cheyne 1722, 222).

\section{b. The alienist grasp on passions: Pinel, on the way to Esquirol}

What changed with Pinel and the alienists - or, in other terms, what might their contribution to the emerging psychiatry have been in this regard? The point is that, where Sauvages added "les secours de la morale" to the medical actions (targeting the blood) upon madness (Sauvages 1772, VIII, 28), Pinel spoke of "traitement moral." The substitution of "traitement" for "secours" expresses that mental disease is wholly located in the medical realm - with its appropriate moral treatment. ${ }^{32}$ As Pinel will claim in

\footnotetext{
${ }^{30}$ See other examples in Cullen 1784, Sauvages 1772, Pinel 1809.

31 The physician should "inspire respect and terror" (Cullen 1784, §1564, on mania).

${ }^{32}$ For various perspectives on moral treatment see Foucault 1965, Swain 1978, Weiner 2001, and "Moral treatment reconsidered" (in Scull 1990).
} 
his Nosographie philosophique, the time is ripe for a "close union, a mutual dependence between moral philosophy and medicine, as Plutarch suggests" (Pinel 1798, II, §9, 12). And, really, the vitalist scheme of "animal economy," not yet wholly accepted by Sauvages - who was still dualistic in his conception of the soul - grounded this Pinelian shift. What was usually termed "medical," like emollients or baths or bleedings, as opposed to "secours moraux," became only a part of a wholly medical attitude which includes relationships, talks, exchanges, moral exhortations, little manipulations and so on. ${ }^{33}$ Foucault argued that "moral treatment" indicated an ascription of madness to the psychological interiority of the human subject, because it somehow relied on the guiltiness the subject originally encloses. ${ }^{34}$ In the present perspective, "moral treatment" is instead understood as systematizing a set of practices (formerly disjoined) that were able to be put together, on a par, because they were different yet equivalent means to reach a same target, i.e., the disturbed animal economy - and being equivalent according to the general equivalence provided by the vitalist doctrine of sensibility.

If the legitimization of moral treatment is so partly entrenched in the animal economy scheme, Pinel's definition and etiology of madness are rather confusedly entangled with this scheme. One can make out here the influence of the Montpellier school on the young alienist, since he attended Sauvages' classes ${ }^{35}$ and was for several years a student in that city, before going to Paris armed with his montpelliérain learning. The animal economy notion enables Pinel to perform a twofold synthesis, between the pathological and the physiological, and between mania and ordinary illness. Indeed, he writes that "the constant laws of the animal economy considered in mania as in other illnesses, struck me as being admirably uniform" (Pinel [1802] 1809, I, §25, 104). Hence, with respect to insanity, we see that his commitment to the animal economy enables him to assume the lawlikeness of madness, precisely insofar as the same laws still hold when illness occurs. The specificity of psychiatric understanding and therapy according to alienism is settled on those grounds, and important consequences concerning public health followed.

Notice that at those times, hospitals entered an important crisis concerning their definition (Foucault 1976, [1978] 1994; Gelfand 1980; Weiner 1993; Ackerknecht 1967, Brockliss and Jones 1997) - facing the questions of what they should do (cure? support? shelter? etc.), to whom (ill people? the disabled? poor or helpless people in general? madmen?), and ruled by whom (priests? doctors? political administrators?). Tenon's and Vicq d'Azyr's important Rapports on hospitals and medicine (Tenon

\footnotetext{
${ }^{33}$ Pinel initiated psychiatry as a specific medical discipline (though the German doctor Johan-Christian Reil invented the successful word "psychiatry"). On the professionalization of this field, chiefly due to Esquirol and the circle of his pupils, see Goldstein 1987.

${ }^{34}$ For example, Foucault 1965, 516, 521, 523 (on the asylum as a "judiciary space from which one is delivered through a version of this trial occurring in the psychological depth").

35 On this training, see Weiner 2001; on Boissier's influential teaching, see Martin 1990.
} 
1788; Vicq d'Azyr 1790), ordered by the royal government, defined possible perspectives of change concerning these institutions, but the French Revolution had to undertake those changes and decide which to implement. ${ }^{36}$ Those decisions were dependent upon the general lines adopted by the committees in charge of medicine.

Hospitals, and moreover psychiatric hospitals, were founded gradually in France, and their purposes were not well defined from the start. In 1797 the hospital in Charenton opened, and then in $1801 \mathrm{La}$ Salpetrière, as a madhouse for women. ${ }^{37}$ However, no specific medicine and physicians were assigned to those hospitals, whose definition merely followed the new imperative asserted by the rapporteurs Tenon and Vicq d'Azyr, to separate big classes of ill people (pregnant women, elderly, lunatics, etc.). When Pinel entered the profession as supervisor for the hospital of Bicêtre and then La Salpetrière, he found already a peculiar configuration in hospitals, and some specific rivalries. Doctors were about to take the lead of hospitals but, as illustrated by the case of the Hotel-Dieu studied by Gelfand (1980), the level of nurses, constituted by religious "nuns" mostly with no medical training, were not disposed to spontaneously obey the medical authority, which in turn wanted to replace them by medical nurses. The other idea, inspired by Tenon, was that concerning insane people hospitals were a means for their cure, so that they had to be built in a specific way, and contain exclusively insane people. The question raised at those times was therefore the definition of who will run the institution - should it be a politician or a physician? Arguments were proffered in favor of both positions. Most of the physicians indeed naturally preferred that a physician be the sole "patron" of the place. This was not obvious when Pinel completed his alienist work, so that his use of animal economy to define the proper take on madness could be seen as another argument intended to strengthen the case for physicians as overseers of asylums.

According to these views, the knowledge of animal economy must form the basis of a medical approach of mental alienation. This is indeed manifest concerning the place of passions. Following the vitalist tradition listed above, Pinel insists on the continuity between passions and alienation. To know alienation, he says, "presupposes a medical history of the passions" because those provoke most of the lunacies, when exacerbated (Pinel [1802] 1809, I, §18, 80). But this etiology is clearly understood only when replaced in the frame of animal economy's sympathies. In fact, mania manifests a

\footnotetext{
${ }^{36}$ The population of hospitals was, as we know, deeply mixed, and being poor was an important criterion for getting allowed into a hospital, which was conceived of as a help for the poor unable to be cured at home by physicians. Vicq d'Azyr wrote: "Hospitals are destined to provide to ailing poor the help needed for their recovery that they cannot get in their houses" (Vicq d'Azyr 1790, 75).

37 The Directoire Exécutif reopened the hospice at Charenton on June 15, 1797, as the "hospice de la Charité de la commune de Charenton, près Paris, connu sous le nom de refuge pour les fous"; its head, de Coulmiers, was not a physician. The Conseil général des Hospices de Paris established that La Salpetrière should be a curing house for insane people in 1802, after the publication of Pinel's treatise. It is to be noted that this resulted from a failed plan to reform all the Parisian institutions dealing with the insane (Swain and Gauchet 1980, 69-75).
} 
"reaction of epigastric forces upon the functions of understanding," which can either increase or oppress those functions (ibid., §9, 27). And Pinel refers to Bordeu and Lacaze regarding the major influence of the epigastric source on "sympathetic tuning," to explain affects in mania's crisis (ibid., $\S 6,16) .{ }^{38}$ The etiology of mania does not necessarilyy involve the brain, if we keep in mind the epigastric-headed order of centers in the animal economy. In the second edition of the Nosographie philosophique, Pinel makes the point that

It is easy to conclude that non-feverish deliriums (délires non fébriles), far from being produced by flaws in the organization of the brain, are always dependent on a strong, vehement passion - both because of the nature of the object of the passion, and the lively sensibility of the subject who experiences it. Now, an internal sentiment relates the effect of these commotions to the epigastric region, whether the center of feeling is located in the pyloric antrum, as Van Helmont claims, in the diaphragm, following Lacaze, Bordeu, and Buffon, or in the solar plexus, as other physiologists argue. Once the impression has been produced at the center of the phrenic forces, the result, following determined laws of the animal economy, is certain disorders in the functions of the understanding, whether in the perception of ideas, imagination or memory, or in the process of judgment or reasoning. Sometimes no disturbance of reason is noticeable, but instead one finds an irresistible inclination to acts of ferocity and barbarism. (Ibid. $§ 7,12$ )

The reader will notice among the references cited here the main vitalist authors, together with the reassertion of the idea that once some phenomena have impinged on the animal economy, "determinate laws" will produce determinate outputs. Pinel clearly relies here on our vitalist proposition (1). Being a perturbation of the animal economy as a whole, insanity according to Pinel is a disease; therefore it requires a specific treatment - which can be, legitimately, physical and moral, because those two registers are homogenous. ${ }^{39}$ Moral treatment becomes a medical practice since alienation is a disease; but it is not a disease of the brain, if we recall the importance of sympathies. So, in a word, within the animal economy scheme, Pinel could undertake a definition of madness as a disease - correlative with the reappraisal of a moral therapeutic practice into medicine - without identifying it as a brain disease, which would have ascribed it to an already constituted part of medicine. That is why he could state that all the bodily reductions of "aliénation mentale" are contradicted by an account of mania: the "animal spirits," the "images traced in the brain," the "unequal

\footnotetext{
38 The same point is made in a note from 1794, attached to the "Tableau des fous de Bicêtre" published by Weiner 1999. "A careful examination of the precursor signs of fits of mania adds striking proof to Lacaze and Bordeu's claims regarding the role of epigastric forces, which Buffon depicts so well in his natural history" ("Tableau," 9 December 1794, in Postel 1981, 229).

${ }^{39}$ Esquirol will share this idea of the sympathies accounting for some lunacies, and in general the major role of epigastric centers in the economy of madness. On this point, see Gauchet and Swain 1980, 334-338.
} 
impulses of blood to the different parts of the brain," 40 do not jibe with the "origin, the causes and the story of the accesses of mania" (ibid., $\S 9,23$ ).

In this regard, recent historiography has advanced two major elements in Pinel's definitive dismissal of the "mistake or sin" conception of insanity: the case of "manie sans délire" (Swain 1978), and the reactivation of the ancient, classical, parallel between passion and mania (Seneca's furor iris breva) (Pigeaud 2002). These analyses are correct and illuminating, but they must be reconnected to our scheme. Only the global conceptions of animal economy, in vitalistic terms (thus emphasizing the epigastric sympathies) could put Pinel in a position to reactivate the old adage. And the possibility of identifying a "manie sans délire," 41 i.e., a madness with no perturbation of ideas, was clearly facilitated - if not conditioned - by the entanglement of insanity with sympathetic centers of sensibility (therefore, its separation from intellectual life).

Disconnected from the mistake-conception of madness (through the use of the animal-economy scheme), different from the Cullenian class of neuroses (thanks to the French vitalistic use of this scheme), Pinel's aliénation mentale was an autonomous class of disease. In the old mistake-conception, curing madness becomes a subclass of moral predication; in the Cullenian nosology, this task was a subset of medicine of the nerves. ${ }^{42}$ Pinel's nosographic conception here differs from Sauvages's or even Cullen's because he avoids identifying a main defect in all alienations (be it diseased perception, or false judgment). Pinel's aliénation mentale was an autonomous class, requiring an independent therapy. ${ }^{43}$ In spite of his continuing use of the Cullenian term "neurosis" in his Nosographie, the Traité de l'aliénation mentale creates something new. This novelty was the specific contribution of the French school of alienism to the general idea of psychiatry, which achieved a consistent articulation in the century to come - and one could trace its later influence into Griesinger's or Georget's synthetic treatises (notwithstanding how deeply different they are in their aims and $\operatorname{roots}^{44}$ ).

\footnotetext{
${ }^{40}$ In fact, this blood-theory of insanity had yet been supplanted by a more neurocentric theory in the late seventeenth century, thanks to authors like Cheyne, Cullen, Unzer, Gaub.

${ }^{41}$ Swain 1978 emphasized the historical importance of the "manie sans délire" for Pinel's achievements.

${ }^{42}$ Granted, Cullen is a main reference for Pinel's medical nosology - one of his first works was a translation of the First Lines, and the reference to English physiology, as well as to British protopsychiatric practice (such as The Retreat at York) is pervasive and well known. On Pinel and British medicine, see Foucault 1965, Weiner 2001, Huneman 2004.

${ }^{43}$ The reality and results of moral treatment in Bicêtre and La Salpetrière have been addressed by Weiner 2001, chap. 7, 217-257, and Postel and Quêtel 1983, 152-160, 314-324.

${ }^{44}$ To some extent German psychiatry instantiated a trend opposed to what Pinel proposed; as Gauchet and Swain (1980, 304f.) pointed out, "historically," the German school in psychiatry "is to be understood as the other of the Pinelian operation" (311) - because it was exactly the alternative between a purely mentalistic and a purely anatomical account of madness (the latter being represented by Meckel's famous Recherches anatomo-physiologiques sur les causes de la folie, Mémoire de l'Académie des Sciences de Berlin, 16, 1760), whereas Pinel's program consisted in superseding this alternative. However, later German psychiatry, as represented by Griesinger, was something different which intregrated some elements from alienism.
} 
In a more general perspective, Pinel's nosological innovation contributed to the global change of attitude towards the insane. Those who question the emergence of asylums, quite at the same time in America, England, and France, as an answer to problems posed by a specific type of population - an answer whose multiple occurrences would call for a structural analysis (Scull 1977; idem 1990) -, have to understand why the insane have been singled out as such. As Andrew Scull wrote,

it should be obvious that before the asylum could emerge as a specialized institution devoted to the problems of insanity, the latter had to be distinguished as a separate variety of deviant behavior not found only among a few upper-class families or confined to cases of furious mania; but existing more pervasively among the lower classes of the community as a distinct species of pathology - a pathology unclassifiable as just one more case of poverty and dependency. (Scull 1977, 341)

Medicalizing insanity was part of the answer - at least in France - and those conceptual shifts operated by Pinel that I have emphasized here largely contributed to this categorization of groups of people, which legitimated the institution of a global and specific response to the problems they posed.

At the same time, something paradoxical does indeed occur here concerning the passions. Pinel makes a twofold move, which eventually breaks with the scheme of an animal economy and announces what is to come with Esquirol. To be sure, passions are included in the etiology and therapy of insanity, which is acknowledged as a disorder of the animal economy (rather than a moral vice pertaining to philosophy, or an organic affection like the frenetic fever, belonging to classical medicine).

The ancient continuity between passion and madness, illustrated by Seneca's slogan furor iris breva (anger is short-lived madness), is therefore interpreted in another framework. As this "non-natural" phenomenon is likely to generate a holistic disturbance of the animal economy, passion exemplifies the putative cause of lunacy because it is indifferently moral and physical, its consequences are recognizable and understandable only by one who, due to her training, is acquainted with the laws of animal economy, namely a physician. Therefore, by vindicating a specific status for alienation, through institutionalizing a medicine proper to it, Pinel contributes to making this continuity of lunacy and the passions (and the therapeutic and etiological modalities by which passions as such - and as normal - interact with lunacy) an object of medical discourse and practice. As Pinel remarks in the preface of the second edition, regarding Crichton's Enquiry, the interesting perspective on passions is "the consideration of passions as simple phenomena of animal economy, with no idea of morality or immorality, and their simple relations with the principles that constitute our being" (Pinel 1809, xxi). Both passion and madness are embedded in the general functioning of animal economy, and thus pertain to the knowledge and practice of medicine rather than to another discourse, be it moral or anthropological. This operation means a radical break with the ancient Stoic slogan, which was intended 
to express how some madness should pertain (like the passions) to ethics and moral predication. $^{45}$

At this point, my analysis is both very close to and very different from Foucault's. Foucault also noticed the role of passions in therapies in the Histoire de la folie (Foucault 1965, 344-347), but he makes no distinction between the uses of the term "passions" over the course of the eighteenth century. He writes

To use passion against démences, this is nothing else than to appeal to the unity of the soul and the body in its most rigorous dimension, to use an event in the dual system of its effects and in the immediate correspondence of their signification. To cure madness through passions supposes that one situates himself in the reciprocal symbolism of the body and the soul. (Ibid., 345)

Here, Foucault rightly noticed that passions were indifferently proper to body and soul, and this underlies their therapeutic impact. However, he wrongly interprets this in the system of "reciprocal symbolism." This may be correct concerning the preceding periods, in the classical age, for example with Boerhaave or Van Helmont, but after Pinel's Treatise passions have this indifferent status because of the medical theories of animal economy proposed by the followers of Bordeu and Lacaze - a status which has nothing to do with symbolism. ${ }^{46}$

Finally, instead of moralizing madness, Pinel medicalizes the passions, in a move which anticipates the century to come. Nothing prevents one from integrating this

${ }^{45}$ In this sense, the shift in the meaning of the passions within psychiatry echoed a trend in the visual culture of the times. It is well known that clinical medicine emerged with a specific language devoted to describing the alterations of tissues or organs at different scales (Foucault 1963). This detailed language was meant to match the possibilities provided by instruments of diagnosis such as percussion etc. in describing the alterations of sick people, as well as what enquiries revealed within the alteration of corpses undertaken by anatomo-pathologists. It was therefore a language easily transcribed into depictions and drawings. Concerning passions, on the other hand, a tradition already existed of iconographic representations of passions seen on the face of people, a tradition exemplified by Le Brun at the end of the seventeenth century (Delaporte 2003). Those drawings were specifically intended to convey not "mental" meanings, in the sense of expressions idiosyncratically proper to the individuals, but rather to capture the specifically physical manifestations of passions on the face of any human being. In this sense, this tradition was more akin to what Pinel and later Esquirol were doing - seeing passions as facts of the animal economy - rather than the usual moralist or anthropological discourse on passions. That is why in the visual culture of the times, Pinel could easily re-appropriate those pictorial achievements, and articulate his own descriptions of mental illness in terms of Le Brun's and others' tradition of depicting passions. The result is that in Esquirol's treatises one would find images of mentally ill people that echo, a century later, Le Brun's illustrations of the passions. It is as if, concerning visual culture, a deep continuity linked Pinel's and Esquirol's achievements to what was undertaken one century earlier, whereas their own conceptualizations of passions, taken as discursive processes, involved a rather significant discontinuity.

${ }^{46}$ Because he overlooks such differences, Foucault is led to overestimate the change happening in the nineteenth century, with Esquirol, the asylums, etc., seeing it as the end of a century-long scheme of madness, and as the emergence of the realm of psychology, interiority, etc. On the contrary, I have tried to show that one aspect of Pinel's and Esquirol's conceptions (namely, the relations between lunacy and passions) relied on a previous medical theory, from the middle of the century, but at the same time departed from it concerning some issues about insanity. 
into a broader Foucaldian framework where what is at stake is the gradual shifting of medicine into a general strategy of power upon populations, essentially tied to the changes of political structures that occurred in early modern times (in the ontological sense of "politics," not in the historical sense of kinds of governments) (Foucault [1981] 1994; idem [1988] 1994). In a more limited way, and restricted to the French case, the rising power of physicians, their striving for legitimacy as both institutionalized professionals and political authorities, ${ }^{47}$ no doubt benefited from this extension of the medical realm towards what was proper to moralists, writers, and all those who thought themselves in charge of the souls of others; more precisely, it may have both benefited such a drive, and been a part of it. ${ }^{48}$ I will therefore consider this institutionalizing of psychiatry and, through Esquirol, its consequences on the anthropology of passions.

\section{The new psychiatry, and what Esquirol had to do with the passions}

Up to this point, even if passions appear as a singular element in the etiologies of the disorders of animal economy, of which insanity constitutes a specific class, requiring "moral treatment," nothing seems specific to the passions, compared to the other "non naturals." It is still far from clear why Esquirol began his career with a giant work on passions. ${ }^{49}$ To understand why at the time there was something obvious about first considering the passions, I have to explicate Pinel's idea of alienation, and how his vindication of the specificity of psychiatry within medicine - hence, of the authority proper to the psychiatrist in the just nascent asylum - departed from the general views of vitalistic animal economy.

As an autonomous disease, irreducible in practice to an error of the mind or to brain lesion, each form of mental alienation actually stems from what Pinel called the "principe de la manie." Discussing an insane person, he writes that "in his incoherent

\footnotetext{
${ }^{47}$ Documented in Weiner 2001, Williams 2003, Goldstein 1987, for several successive periods.

${ }^{48}$ Regarding the increased authority of medicine upon madness, Scull appeals to general Weberian insights regarding the process of rationalization in capitalist societies: "On the most general level, the English elite was receptive to the notion that a particular occupational group possessed a scientifically based expertise in dealing with lunacy. This receptivity reflected the growing secular rationalization of Western society at this time; a development which, following Weber, I would argue took place under the dominant, though not the sole, impetus of the development of a capitalist market system" (Scull 1977, 344). The role of medicine in France somehow paralleled this evolution; one could see the shift of meaning of passions as a detail in this general process, which supports the legitimacy of medicine as regards madness and deviance in general.

${ }^{49}$ Swain and Gauchet 1980 offer an insightful and exhaustive examination of Esquirol's thesis. However, the problems of the present paper are much more "local," as their topic concerns the transformations of rationality in modern France, and yields a general interpretation of modernity. Nevertheless, when they conclude that Esquirol used the passions to "push madness out of the class of troubles of the brain machinery stricto sensu, and a fortiori out of the domain defined by 'metaphysicians' as that of spirit, in order to ascribe madness to the individual taken as a whole, body and soul included and conflated" (Swain and Gauchet 1980, 302), their view plainly matches what I have concluded from Pinel's and later Esquirol's use of the vitalist "animal economy" scheme.
} 
ideas, one can make out the principle of his mania" (Pinel [1802] 1809, §23, 98). Here lies the main difference between moral practices used by the physicians of "économie animale" and Pinel's "moral treatment": the latter is grounded in "the principle of the mania," it belongs to this autonomous psychiatric space postulated by the Traité, and not least - it requires a medical specialist; the usual vitalist physician will notice a general disturbance of animal economy but won't be able to capture the "principle of the mania," always at work at the basis of each form of insanity, and susceptible to be understood by the sole examination of large diversified sets of lunatics.

The "principle of mania" is somehow coalescent with the asylum institution, because the physician must deal with a multiplicity of maniacs, in order to differentiate the "principles" of mania, and pick out the main classes. Such a concept can not be raised in the context of a face-to-face relationship between one patient and the doctor, as the therapeutic relation had been practiced during centuries. Now, the "moral treatment" can revolve around one man, possessing this insight upon a subject, and therefore able to achieve the two aims of moral treatment: breaking the association of ideas, causing a salutary shock on the whole animal economy. In fact, in order to apply the treatment, says Pinel, "there must be a narrow dependence upon a man who, through his physical and moral virtues, would be proper to exert upon the insane an irresistible power, and to change the vicious chain of his ideas" (ibid., I, §6, 58). ${ }^{50}$ Defining the psychiatrist as one who has some kind of insight implies creating a special relationship between the doctor and his patients, hence the presence of the alienist among them. With this move, Pinel definitively strengthened the case for physicians as directors of madhouses - even if in practice this had to await the professionalization of psychiatry, and the fight of Esquirol and his pupils, to be institutionalized in the law (Castel 1976). For this reason also, Esquirol will say: "One must live with the lunatics, in order to get exact notions about symptoms, causes, order, crisis, and end of their illness" ("De la folie," in Esquirol 1838, I, 59). Of course, such inflexion of moral therapeutics entails a trend towards sequestration of the patients, all confronted to the psychiatrist - and it is historically what happens, with the emergence of mental asylums, and their legal promotion in France with the 1838 law, promoted by Esquirol's circle. ${ }^{51}$ As Georget wrote in 1820 :

The doctor is the director of the workplace, nothing can happen there that is not under his orders or following his orders. . . The control [gouvernement] of the insane must be absolute; all questions are to be decided without appeal, by the doctor . . . he also exerts great power over the patients, as a man. (Georget [1820] 1971, chap. 5, §1)

\footnotetext{
50 “Il faut l'étroite dépendance d'un homme qui, par ses qualités physiques et morales, soit propre à exercer sur l'aliéné un empire irrésistible, et à changer la chaîne vicieuse de ses idées." The therapeutic relevance and use of the alienist's singular personality is entirely part of Pinel's legacy.

${ }^{51}$ On the vindication for asylum and psychiatry see Goldstein 1987, Huneman 2004, Huneman (forthcoming), Castel 1976.
} 
At this point, we can state the precise convergence between conceptual and institutional innovations. The "principle of the mania" definitively singled out some classes of deviant people as insane, insanity being the proper object of study of a specific kind of physician; at the same time, they should be managed - to take a word from Scull (1990) - in specific institutions, necessarily ruled by those specific physicians who are in charge of them. Notice that the size of such institutions has been controversial; once again, Esquirol's trajectory is paradigmatic: starting in 1805 as director of a small "maison," a private clinic for mostly rich psychiatric patients, supposed to be the best option for practicing the moral treatment, he will finally embrace the advantages of large hospitals, while writing his 1818 Mémoire to the Ministère de l'Intérieur (Esquirol 1819). ${ }^{52}$ This turn would provide evidence for Scull's thesis since, as a large institution, the psychiatric hospital may appear as a systematic, medicine-based solution to the management of some categories of people with very diverse behaviors but as a whole unable to attend to the labor market.

External reasons for which the insane should be handled in a specific way investigated by Scull (1977, 1979, 1990) for England and America, and which have to do with general changes of economic regime and status of workers in industrial capitalism (especially, the necessity of having a clear-cut distinction between those who were able to enter a job market and those who were not) - converged with those conceptual reasons that justified putting together all cases of "insane" people and addressing them through the skills of a specific brand of medicine. This perfectly defines the circularity pointed out by Scull ${ }^{53}$ (analyzing the cases of America and England) through which the appropriation of insanity by doctors of the insane was both legitimized and justified by putting the insane aside, out of society and into medical institutions. We can now grasp what will systematically emerge in Esquirol's work, and settle the status of passion as a new medical object in the nineteenth century. Everything here hinges on the consequences of Pinel's concept of a "principle of the mania."

First, the revision of the classification with the Esquirolian concept of "monomania" (i.e., a delirium with a single object, nonetheless not necessarily sad like in melancholia) derives from this concept. If we look at the concept of mania, Pinel's division between mania and melancholia is not fine-grained enough, because the meaning of the specific passions involved in the delirium is therapeutically and etiologically relevant since it

\footnotetext{
${ }^{52}$ He writes: "Those subdivisions, today necessary for any well ordered insane asylum, would not be done in an asylum intended to include a small number of individuals, because there would be as much subdivisions as individuals" (Esquirol 1838, 266). Esquirol here justifies by medical reasons (more precisely, by appeal to the feasibility of medical practice) the large extension of asylums.

53 "Just as the separation of the insane into madhouses and asylums helped to create the conditions for the emergence of an occupational group ('mad-doctors') laying claim to expertise in their care and cure, so too the nature and content of the restorative ideal these doctors espoused reinforced the commitment to the institutional approach. Thereafter, the existence of both asylums and psychiatry testified to the 'necessity' and 'naturalness' of distinguishing the insane from other deviants" (Scull 1977, 345).
} 
concerns precisely the "principle of the mania." Melancholia is a fixation on one idea, but grasping the principle of a given disorder entails understanding in what consists, this time, such idea; and the insane being fixed on such idea bears a similarity to a normal subject having a slight fixation to some idea, which means a human being getting passionate about something. ${ }^{54}$ Among all the possible etiologies of lunacy, passion appears to be uniquely relevant from the moment one considers not only the fact of the fixation on one idea, but the content of this idea, in order to devise a more fine-grained taxonomy (at least, of melancholia), and, plausibly, a more accurate therapeutics. This is exactly what is at stake in the new relations between passion and insanity, which govern Esquirol's work Des passions.., and will continue to govern his understanding of psychiatry. Thereby he can claim that we have to find the "ruling passion" (passion dominante) in each form of alienation, and then categorize those forms of alienation into taxonomic classes: kinds of "monomania" ("De la monomanie," Esquirol 1838, I, 333f.). ${ }^{55}$ This idea of a "ruling passion" is again used by Esquirol when he reinterprets the question raised by Pinel: are there more insane people since the Revolution, and more generally, is there a link between historical periods and kinds of insanity? The nature of this link, answers Esquirol, is that precisely each epoch has a passion proper to it - hence the dominance, in each period, of the monomania associated with this passion.

Secondly, the criteria of a successful cure cannot be something visible, it must be connected to the insight and abilities of the psychiatrist. For this reason, the manifest ending of delirium is not enough to establish a diagnosis of mental health because the principle of mania can secretly be active, but hidden to the lay people. Esquirol's criterion, then, is the return to the old passions - family, work, etc.: this change alone can indicate a genuine healing. "There are patients whose disorder is barely noticeable - there are none whose passions and moral affections are not disordered, perverted or annihilated" ("De la folie," Esquirol 1838, I, 8). Therefore the sign of the recovery of health is a "return to the rhythm of ordinary life," rather than the end of delirium. Passions, through the reinterpretation of the doctrines of non-naturals, Pinel's reinterpretation of animal economy, and finally Esquirol's reading of melancholia as expressing a ruling passion as the principle of the madness (the object of the alienist), became crucial for diagnosing and curing various forms of insanity; now, they are also among the criteria of healing that solely the medical specialist can use.

To this extent, modern psychiatry achieves its separation with the medicine of the vitalists which was the locus of its emergence. Madness is then a general disorder of the economy, yielded by a specific kind of principle. To be sure, alienists retained some features of the animal economy medicine, that were present in the conceptual possibility

\footnotetext{
${ }^{54}$ According to its concern with identifying the content of the specific passion in each monomania, Esquirol wanted to reform the psychiatric lexicon of melancholia, substituting "lypemania" for some of its forms. On this failed reform, see Swain, "Permanence et transformations de la mélancolie," in Swain 1994, 167-187.

${ }^{55}$ On Esquirol's classification, see Bercherie 1980, chap. 2.
} 
of the moral treatment; but in the end Pinel and Esquirol broke with this scheme of animal economy and the kind of "natural history of man" supposed to be improved by such framework. Passion is no longer this "non-natural" circulating in the animal economy under various modes of sensibility, it now connects to madness and to its possibility, to the extent that madness relies on a principle that neither classical medicine nor ordinary ethics or epistemology à la Locke or Condillac could detect. The era of volumes of moral philosophy entitled "Treatise on the Passions" surely concluded with the works of Tissot, Gregory or Le Camus, and with the anthropological ambition of vitalist physicians; but Esquirol now closes this anthropology of passion belonging to the eighteenth century - medicine, passions, and madness enter into new interrelations.

Andrew Scull, relating the emergence of psychiatry at the same time in Anglo-Saxon countries to the rise of capitalism, spoke of psychiatrists as "moral entrepreneurs." According to him, they were trying to sort and readapt through moral treatment potential workers removed from the market, so that they could reinternalize "bourgeois morality." "Just as those who formed the new industrial work force were to be taught the 'rational' self-interest essential if the market system were to work, the lunatics, too, were to be made over in the image of bourgeois rationality: defective human mechanisms were to be repaired so that they could once more compete in the marketplace" (Scull 1990, 94). In this regard, the new status of passions fits this picture. Passions are the connection between the class of insane people and normal people in a first sense, the mad doctor has to reintegrate the lunacy within the "history of passions" of the subject, which provides etiological and therapeutic clues; on the other hand, switching from the "ruling passion," once identified, as Esquirol says, to the "old passions" proper to family and work, exactly defines the kind of cures the alienist is supposed to take up. The complex status of passions therefore expresses both the exteriority of the insane to the world of working ordinary people with their usual passions, their connection to it, and finally the possibility of reintroducing them to it. The conception of passions sketched here, then, is not independent from the social transformations that underpinned the rising status of psychiatrists - on the contrary, it was tied (far better than the old, classical, view of passions as expressions of a dualism) to the dual status of lunacies, lumped together into a nosological entity which was both external to the social world of those people marrying, parenting, and working, and (thanks to asylums and their doctors) still likely to reintegrate that social world: the proper status of a class of people which had to be "managed" by a class of specialists.

\section{Conclusion}

Crudely put, seventeenth century passions are a disturbance of the soul by the body. They were (simultaneously and for the same reasons) something not understandable by the Cartesians and their followers - because they involved the union between body and soul, this absolute ontological mystery of the reunion of two distinct 
substances - and an essential theoretical issue. Passion, for the physicians in the Encyclopedie, and more generally for the tenets of a vitalistic anthropology, has another nature. It does not rely on the same relations between body and soul. Briefly, the theoretical problem is inverted: now, the unity of body and soul is less an original mystery than it is a basic self-evident fact. Henceforth, all that has been said about the relations between madness and passion, through the topic of déraison (brilliantly analysed by Foucault), is no longer valid.

Pinel actually tended to specify a new kind of disorder, named "mental alienation," to vindicate a proper kind of therapy, and to contribute in France to the institutionalizing of a new kind of medical specialty, precisely because he did not raise the question of the bodily or mental nature of this disorder and of its aetiology. The animal economy medicine was the reason of this avoidance. The two metaphysical positions - soul-centered, brain- or body-centered - being neutralized, this allowed a specific kind of medicine, vindicating for itself what used to be called "diseases of the soul."

In this context, it is no wonder that passions, those "disorders of the soul" as a venerable moral tradition considered them, have been affected at first stake by those theoretical changes. In mid-eighteenth century anthropology, they are no longer conceivable as disorders of the soul, because they are caught in an economy composed of reciprocal affections between sensible elements. They are understood through the renewed category of the non-naturals. But when mental disorder, slowly and through the use of this anthropology initiated by Pinel and concluded by Esquirol, emerged as a general and irreducible disorder of the animal economy, passions reappeared yet in another locus, different from the initial one. They were now constituted into a theoretical object in the sole field that could now give an autonomous consistency to an illness concerning souls - namely, psychiatry. This is not to say that the century of the vitalists prepared an era where passion is psychiatric - but it seems that the theoretical discourse (not the literary one) on passions will be, from Esquirol on, fundamentally affected by the emergence of psychiatry. What happened is that the passions, which were formerly a key issue and object in seventeenth-century treatises on the passions because they were the object of a theoretical interest obviously derived from the problem of the relations between body and soul - were omitted as such from the new French anthropology centered around the vitalists' animal economy as a proper theoretical object; yet this discourse that dissolves the passions is precisely what will later allow the emergence of the new discourse of alienism at the end of the century, within which passion gains a renewed significance. Passion thereby reappears after what could be seen as an inversion: the madman, in seventeenth-century tragedy and morals, is like a hyperbole of passion - madness as déraison is a metaphor as well as a way to approach this affected reason that we call passion. With Esquirol's completion of Pinel's move to animal economy medicine, on which this paper has focused, these relations got inverted, so that passion is like the way to a knowledge of madness. The Pinelian theory of the principle of mania motivates this new theoretical interest about passions, because under 
its Esquirolian name of "ruling passion," it refers to that which, among the familiar items, seems the closest to such a strange "principle" that proved essential for the very existence of psychiatry. Because passion ceased to be anthropologically outstanding and metaphysically revealing in the mid-eighteenth century in the epistemological structure of vitalist physiology and medicine, and within the anthropological image that elaborated on it, passion could finally become epistemologically crucial in a very special locus: the place where the lunatic, as an object of knowledge and control by the medical specialists, can only be approached and understood through his proximity with the passionate human being. Hence the grammar of passions is now less a propaedeutic towards the knowledge of man and his moral edification, than a theoretical overture towards his many possibilities of being insane.

My analysis has focused on the changes that appeared in France in the wake of Montpellier vitalism. As I emphasized, some novelties concerning the management of the insane were parallel in France and England. The theoretical bases on which the English and Americans justified those innovations however may have been different, even if the result was always the singling out of one category of people, the insane, as likely to be managed by a specific medicine in a specific place. Further analyses should also examine German physiology and its link to German psychiatry. Anthropology as practiced by German physicians (Plattner, Hufeland ${ }^{56}$ ) had a distinctive view of the passions, and German psychiatry may have partly inherited them. However it is plausible to say that aspects of the anthropological view which Pinel elaborated on the basis of vitalism were reappropriated by the German discourse on madness, as the example of Hegel's Enzyklopädie makes clear (Hegel [1830] 1965, Add. §4 08, 207-221). ${ }^{57}$ This means that the ontological status of madness and the insane, as well as some institutional facts that it legitimated, was not absolutely different in Germany. This would also imply that the specific relation between passions and madness which emerged in the French context may have been to some extent similar in Germany. Nevertheless, the German situation was rather different in terms of social and economic aspects, and this should lead us to be cautious while investigating the similarities that philosophical or medical treatises of madness in Germany in the nineteenth century bear with the French ones.

\section{Acknowledgments}

I warmly thank Stéphane Schmitt for his careful reading and suggestions, and Charles Wolfe for his terrific editing and rewriting of this paper

\footnotetext{
${ }^{56}$ Ernst Plattner, Anthropologie für Ärtze und Weltweise, 1772 ; Christoph Hufeland, Makrobiotik, oder Die Kunst, das menschliche Leben zu verlängern (1796). On this anthropology, see Linden 1979; Regenspurger and Zantwijk 2005.

${ }^{57}$ Hegel freely comments on Pinel's division of madness, bringing out the conceptual articulation that is supposed to underpin it. See Swain's commentary, “De Kant à Hegel," in Swain 1994, 1-28.
} 


\section{References}

Ackerknecht, Erwin. 1967. Medicine at the Paris hospital. Baltimore: Johns Hopkins Press.

Arnold, Thomas. 1782. Observations of the Nature, Kinds and Prevention of Insanity, Lunacy or Madness. Leicester: G. Ireland.

Barthez, Paul-Joseph. 1801. Discours sur le génie d'Hippocrate. Montpellier: Tourmel.

Barthez, Paul-Joseph. 1806. Nouveaux éléments de la science de l'homme, 2nd ed., 2 vols. Paris: Goujon \& Brunot.

Beauchesne, Pierre. 1781. De l'influence des affections de l'âme dans les maladies nerveuses des femmes, avec le traitement qui convient à ces maladies. Montpellier: Méquignot.

Bénichou, Paul. 1988. Morales du grand siècle. Paris: Gallimard.

Bercherie, Paul. 1980. Les fondements de la clinique. Paris: La Bibliothèque d'Ornicar.

Bichat, Xavier. 1800. Recherches physiologiques sur la vie et la mort. Paris: Béchet.

Blanckaert, Claude. 2002. "1800. Le moment "naturaliste" des sciences de l'homme." Revue d'Histoire des Sciences humaines 3(2):117-160.

Bordeu, Théophile. 1751. Recherches anatomiques sur la position des glandes et leur action. Paris: Quillau père.

Brockliss, Lawrence and Colin Jones. 1997. The Medical World of Early Modern France. Oxford: Clarendon Press.

Buffon, George Louis Leclerc. 1749-1758. Histoire naturelle, générale et particulière. Paris: Imprimerie royale.

Brown, Theodore. 1985. "Descartes, Dualism, and Psychosomatic Medicine." In The Anatomy of Madness, edited by William, F. Bynum, Roy Porter, Michael Shepherd, vol. 1, 40-62. London: Tavistock Press.

Bynum, William. 1980. "Health, Disease and Medical Care." In The Ferment of Knowledge, edited by George, S. Rousseau and Roy Porter, 211-54. Cambridge: Cambridge University Press.

Castel, Robert. 1976. L'ordre psychiatrique. L'âge d'or de l'aliénisme. Paris: Minuit.

Cheyne, George. 1742. Natural Method of Cureing the Diseases of the Body, and the Disorders of the Mind Depending on the Body. London: Strathan.

Crichton, Alexander. 1798. An inquiry into the nature and origin of mental derangement, comprehending a system of the physiology and pathology of the human mind, and a history of passions and their effects. London: Cadell and Davies.

Cullen, William. 1761. Lectures on materia medica. Dublin: Whitestone.

Cullen, William. 1784. First Lines in the Practice of Physicks. London: Cadell.

D’Aumont, Arnulphe. 1765a. "Délire." Encyclopédie. IV: 785-788. Paris: Briasson.

D’Aumont, Arnulphe. 1765b. "Démence (Médecine)." Encyclopédie IV: 807-808. Paris: Briasson.

D’Aumont, Arnulphe. 1765c. "Phrénésie." Encyclopédie XII. 530-53. Paris: Briasson.

Delaporte, François. 2003. Anatomie des passions. Paris: PUF.

Descartes, René. 1649. Les passions de l'âme. In Descartes, Euvres, edited by Charles Adam \& Paul Tannery, vol. XI. Paris: Vrin, reprint 1996.

Esquirol, Jean Etienne Dominique. 1805. Des passions considérées comme causes, symptômes et moyens curatifs de l'aliénation mentale. Paris: Didot.

Esquirol, Jean Etienne Dominique. 1819. Des établissements d'aliénés en France et des moyens d'améliorer le sort de ces infortunés. Mémoire présenté à son Excellence le Ministre de l'Intérieur. Paris: Huzard.

Esquirol, Jean Etienne Dominique. 1838. Des maladies mentales. Paris: Baillière.

Falconer, William. 1788. A Dissertation on the Influence of the Passions upon the Disorders of the Body. London: C. Dilly and J. Phillips.

Foucault, Michel. 1963. Naissance de la Clinique. Paris: PUF.

Foucault, Michel. 1965. Histoire de la folie à l'áge classique. Paris: Gallimard (2nd ed).

Foucault, Michel. 1976. "La politique de la santé au XVIIIème siècle." In Les machines à guérir. Aux origines de l'hôpital moderne, 11-21. Paris: Institut de l'Environnement.

Foucault, Michel. [1978] 1994. "L'incorporation de l'hôpital dans la technologie moderne." In Dits et écrits III, 508-521. Paris: Gallimard. 
Foucault, Michel. [1981] 1994. “'Omnes et singulatim': vers une critique de la raison politique.” In Dits et écrits IV, 134-161. Paris: Gallimard.

Foucault, Michel. [1988] 1994. "La technologie politique des individus." In Dits et écrits IV, 813-828. Paris: Gallimard.

Franchet, Joseph. 1798 [An VI]. Maladies affectées aux divers âges. Montpellier, dissertation of the faculty of medicine.

Gelfand, Toby. 1980. Professionalizing Modern Medicine: Paris Surgeons and Medical Science and Institutions in the 18th Century. London: Greenwood Press.

Georget, Etienne. [1820] 1971. De la folie. Edited by Jacques Postel. Paris: Crevot; reprint, Toulouse: Privat.

Goldmann, Lucien. 1955. Le dieu caché. Étude sur la vision tragique dans les Pensées de Pascal et dans le théâtre de Racine. Paris: Gallimard.

Goldstein Jan. 1987. Console and Classify: The French Psychiatric Profession in the Nineteenth Century. Cambridge: Cambridge University Press.

Grange, Kathleen. 1961. "Pinel and Eighteenth-Century Psychiatry." Bulletin of the History of Medicine 35:442-453.

Grmek, Mirko. 1970. "La notion de fibre vivante chez les médecins de l'école iatrophysique." Clio medica 5:308-315.

Gregory, John. 1777. A Comparative View of The State and Faculties of Man with Those of the Animal World. Edinburgh: Dodsley.

Hegel, Georg Wilhelm Friedrich [1830] 1965. Enzyklopädie. III. Philosophie des Geiste, ed. by Hermann Glockner. Stuttgart: Fromann Verlag.

Huneman, Philippe. 1998. Bichat. La vie et la mort. Paris: PUF.

Huneman, Philippe. 2004. "Les théories de l'économie animale et la naissance de l'aliénisme." Psychiatrie, Sciences humaines, Neurosciences 2(2):47-59.

Huneman, Philippe. 2007. "'Animal Economy': Anthropology and the Rise of Psychiatry from the Encyclopédie to the Alienists." In The Anthropology of the Enlightenment, edited by Larry Wolff and Marco Cipolloni, 262-276. Stanford: Stanford University Press.

Huneman, Philippe. 2008. Métaphysique et biologie. Kant et la constitution du concept d'organisme. Paris: Kimé.

Huneman, Philippe. (forthcoming). "Pinel - écrire le cas." In L'écriture des médecins idéologues, edited by Béatrice Didier. Grenoble: Presses de l'Université de Grenoble.

Jackson, Stanley. 1986. Melancholia and Depression: From Hippocratic to Modern Times. New Haven: Yale University Press.

Kaufmann, Doris. 1995. Aufklärung, bürgerliche Selbsterfahrung und die "Erfindung" der Psychiatrie in Deutschland, 1770-1850. Göttingen: Veröffentlichungen des Max-Planck-Instituts für Geschichte, vol. 122.

de La Caze, Louis. 1755. Idée de l'homme physique et moral pour servir d'introduction à un traité de médecine. Paris: Guérin \& Delatour.

Laroque, Raymond. 1798 [An VI]. De l'influence des passions sur l'économie animale, considérée dans les quatre âges de la vie. Montpellier, dissertation of the faculty of medicine.

Le Camus, Antoine. 1753. Médecine de l'esprit, où l'on traite des dispositions et des causes physiques qui sont des conséquences de l'union de l'âme avec le corps, influant sur les opérations de l'esprit; et des moyens de maitriser ses opérations dans un bon état ou de les corriger quand elles sont viciées. Paris: Ganeau.

Linden, Mareta. 1979. Untersuchungen zum Anthropologiebegriff des 18. Jahrhunderts. Frankfurt: Peter Lang.

Martin, Julian. 1990. "Sauvages' nosology. Medical enlightenment in Montpellier." In The Medical Enlightenment of the Eighteenth Century, edited by Andrew Cunningham and Roger French, 111-138. Cambridge: Cambridge University Press.

Ménuret de Chambaud, Jean-Joseph. 1765a. "Manie.” Encyclopédie. X:31-34. Paris: Briasson. 
Ménuret de Chambaud, Jean-Joseph. 1765b. "Mélancholie.” Encyclopédie. X:308-311. Paris: Briasson.

Ménuret de Chambaud, Jean-Joseph. 1765c. “conomie Animale (Médecine).” Encyclopédie. XI:360-366. Paris: Briasson.

Nutton, Vivian. 1993. "Humoralism." In Companion Encyclopedia of the History of Medicine, vol. 1, edited by William, F. Bynum and Roy Porter, 281-291. London: Routledge.

Pigeaud, Jackie. 2002. Aux portes de la psychiatrie. Pinel, l'ancien et le moderne. Paris: Flammarion.

Pinel, Philippe. [1802] 1809 [An IX]. (2nd ed.). Traité médico-philosophique de l'aliénation mentale. Paris: Richard, Caille, et Ravier.

Pinel, Philippe. [1798] 1813 (6th ed.). Nosographie Philosophique. Paris: Richard, Caille, et Ravier.

Porter, Roy. 1987. Mind-Forg'd Manacles: A History of Madness in England from the Restoration to the Regency. Cambridge: Harvard University Press.

Porter, Roy. 2003. Madness: A Brief History. Oxford: Oxford University Press.

Postel, Jacques. 1981. Genèse de la psychiatrie - les premiers écrits de Philippe Pinel. Paris: Le Sycomore.

Postel, Jacques, and Claude Quêtel, eds. 1983. Nouvelle histoire de la psychiatrie. Toulouse: Privat.

Regenspurger, Katja and Temilio van Zantwijk, eds., 2005. Wissenschaftliche Anthropologie um 1800? Wiesbaden: Franz Steiner.

Reill, Hans Peter. 2005. Vitalizing nature in the Enlightenment. Chicago: University of Chicago Press.

Rey, Roselyne. 1992. "Buffon et le vitalisme." In Buffon 88, edited by Jean Gayon, 400-415. Paris: Vrin.

Royer, G. 1803. De l'influence des passions considérées sous le rapport médical Paris, dissertation of the faculty of medicine.

Scull, Andrew. 1977. "Madness and Segregative Control: The Rise of the Insane Asylum." Social Problems 24(3):337-351.

Scull, Andrew. 1979. Museums of Madness: The Social Organization of Insanity in Nineteenth Century England. London: Allen Lane/New York: St. Martin's Press.

Scull, Andrew. 1990. Social Order/Mental Disorder: Anglo- American Psychiatry in Historical Perspective. Berkeley: University of California Press.

Scull, Andrew. 1993. The Most Solitary of Afflictions: Madness and Society in Britain 1700-1900. New Haven and London: Yale University Press.

Scull, Andrew and Jonathan Andrews. 2001. Undertaker of the Mind: John Monro and Mad-Doctoring in Eighteenth-Century England. Berkeley: University of California Press.

Boissier de Sauvages, François. 1772. Nosologie méthodique, ou distribution des maladies en classes, genres et espèces selon l'esprit de Sydenham et la méthode botanique. Lyon: Mercier.

de Sèze, Raymond. 1786. Recherches philosophiques et physiologiques sur la sensibilité ou la vie animale. Paris: Prault.

Steinke, Hubert. 2001. "Haller's Concepts of Irritability and Sensibility and their Reception in France." In Mécanisme et vitalisme, edited by Mariana Saad, La lettre de la Maison française d'Oxford 14:37-69.

Steinke, Hubert. 2005. Irritating Experiments: Haller's Concept and the European Controversy on Irritability and Sensibility, 1750-90. Amsterdam and New York: Rodopi.

Swain, Gladys. 1978. Le sujet de la folie. Paris: Payot.

Swain, Gladys. 1994. Dialogue avec l'insensé. Paris, Gallimard.

Swain, Gladys and Marcel Gauchet. 1980. La pratique de l'esprit humain. Paris: Gallimard.

Tenon, Jacques. 1788. Mémoire sur les hôpitaux. Paris: Pierres.

Tissot, Clement-Joseph. 1798. De l'influence des passions de l'âme dans les maladies. Paris: Koenig.

Vicq d'Azyr, Félix. 1790. Nouveau plan de constitution pour la médecine en France. Présenté à l'Assemblée Nationale par la Société Royale de Médecine, s.l., p. 135-136.

Weiner, Dora. 1993. The Citizen-Patient in Revolutionary and Imperial Paris. Chicago: University of Chicago Press.

Weiner, Dora. 1999. "Observe and Heal: Philippe Pinel's Experiment at the Salpêtrière Hospice, 18021805." In Knowledge and Power: Perspectives in the History of Psychiatry, edited by Eric, J. Engstrom, Matthias, M. Weber, and Paul Hoff, 25-43. Berlin: Verlag für Wissenschaft und Bildung. 
Weiner, Dora. 2001. Comprendre et soigner. Paris: Fayard.

Whytt, James. 1765. Observations on the Nature, Cause, and Cure of Those Disorders Commonly Called Nervous, Hypochondriac or Hysteric. Edinburgh: Hamilton.

Williams, Elisabeth. 2003. A Cultural History of Medical Vitalism in Enlightenment Montpellier. London: Ashgate.

Wolfe, Charles, T. and Motoichi Terada. "The Animal Economy as Object and Program in Montpellier Vitalism," in this issue. 